\title{
栄養判定指数と骨発育成熟度との関連に関する研究
}

\author{
小西 博 喜* 大山 良 徳**

\section{A STUDY ON THE RELATIONSHIP BETWEEN BONE MATURATION SCORES AND NUTRITION INDEXES}

\author{
HIROKI KONISHI AND YOSHINORI OHYAMA
}

This study was to examine the relationship between bone maturation scores and the nutrition indexes, and to consider the estimated range for the evaluation of bone maturation scores. This study investigated the relationship between the bone maturation scores and the nutrition indexes of compound variables of height, body weight and sitting height, by the correlation coefficients in eleven items and used them as raw data for analysis.

The obtained results were as follows :

1. The correlation coefficients between the nutrition indexes and bone maturation scores (Middle Phalanges) showed that in the second sexual period boys were significance at the level 0.05 in all the Rohrer, Kaup and Kawahata indexes. Each of them were as follows : Rohrer index 0.325, Kaup index 0.415, Kawahata index 0.485 . In the girls also the correlation coefficients showed significance between the Rohrer, Kaup, and Kawahata indexes of all three phalanges scores, especially in correlation with the Middle Phalanges scores : Rohrer index 0.458 , Kaup index 0.540 , Kawahata index 0.424 .

2. If the bone maturation scores are evaluated by the three nutrition indexes, it may be estimated that the bone maturation scores are evaluated by the Middle Phalanges scores for both boys and girls.

Regression Equations and the Standard Error (S.E.) of estimate are as follows :

Rohrer Index ; Boys : $\mathrm{Y}=12.42+0.75 \mathrm{X}, \mathrm{S} . \mathrm{E} .= \pm 0.15$

Girls : $Y=10.00+1.55 X$, S.E. $= \pm 0.38$

Kaup Index; Boys : Y $=10.48+0.62 X$, S.E. $= \pm 0.21$

Girls : $\mathrm{Y}=8.23+1.13 \mathrm{X}, \mathrm{S} . \mathrm{E} .= \pm 0.35$

Kawahata Index ; Boys : $\mathrm{Y}=10.47+1.82 \mathrm{X}, \mathrm{S} . \mathrm{E} .= \pm 0.21$

Girls : $Y=12.08+2.66 X$, S.E. $= \pm 0.29$

note : $\mathrm{X}$ (nutrition indexes) $\mathrm{Y}$ (bone maturation scores)

3. The S.E. of estimated scores in bone maturation scores which were obtained by using each the nutrition index scores of the estimate equations were very small and the results of $t$-Test in the means of estimated scores and the means of actual measurement showed hardly any significant difference at the level 0.01 . According to these results the estimate equations used here were considered to be of higher reliability.

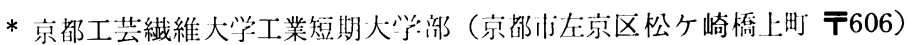
College of Technology, Kyoto Technical University, Sakyo-ku, Kyoto (606)

**大阪大学健康体育部（些中方待兼山町 干560） Osaka University, Toyonaka, Osaka (560) 
4. The bone maturation scores were compared with the two groups, good and poor, classified by the nutrition indexes. In the case of the boys there was no significant difference in the Rohrer index.

But according to the Kaup and Kawahata indexes there were significant differences in each part of the bone except for the Proximal Phalanges scores. In the girls there were equally significant differences in all three nutrition indexes of the good-poor groups.

From the results found in this study, the nutrition indexes may by considered as an index to estimate the bone maturation scores, at least, of junior high school students in growing period.

(J. Physical Fitness Japan 1982, $31: 82 \sim 93$ )

\section{緒}

栄養判定指数（以下栄養指数という）に関する 研究報告1) 14)22225) はこれまでに数多くみられる。 一般的に栄畕指数は肥満度の判定に広く利用され ているが，栄意指数の特性および指数とその他の 生体现象との関連汇関する研究は少ないようであ る。

筆者らは, これまで栄養指数の特性（栄雀指数 之呇養掑取量）および指数之生体現㿝（運動能 力・进動機能 $)^{11121)}$ との関連について叮らかにし てきた。一方, 骨発育成熟度と身体発育変量との 関係は，大原がさきに小中学徒の身体の発青発達 之骨成熟汇関する研究 ${ }^{17)-20)}$ の中で詳述している が，乙机は骨発育成熟度と身体発育变量（身長・ 体重・胸囲・座高）との関保をこれぞれ独立汇検 討したものである。

本研究では，できれば数多くの身体発育変量を 組み合わせて評価した值を単独変量として用いた 方が妥当性の高い関係を解明しうるという立場か

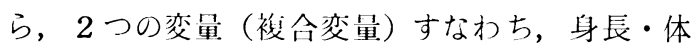

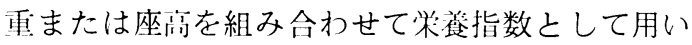
た。したがって, 本研究は複合変量を用いて評価 する Rohrer, Kaup, Kawahata 指数の 3 つの栄養 指数之骨発育成熟度との関連を考察し,さらに, 骨発育成熟度評価のための推定の簌囲を明らかに することである。同時に，また栄養指数が骨発育 成熟度を推定する 1 つの指標となるかについても 検討した。

なお,ここでいう Rohrer, Kaup, Kawahata 指数の各指数は, 一般に栄養状態之肥満・やせと の関係を示す指数として採用されているという理 由により栄養指数とよぶことにする。すなわち，
Rohrer, Kaup, Kawahata Index を用いて筷㓌状 態を推测する1つの便法としたわけである。

\section{研 究 方 法}

標本は京都市内にある $\mathrm{S}$ 中学校 2 年生男子 37 名，女子 45 名，介計 82 名を対象とした。

测定项目之して，1）栄養指数は Rohrer 指 数 (体重 $\left./(\text { 身长 })^{3} \times 10^{5}\right)$, Kaup 指数（体重， $\left.(\text { 身長 })^{2} \times 10^{3}\right)$, Kawahata 指数 $\left(\right.$ 体重 $/(\text { 座高 })^{2} \times$ $\left.10^{3}\right)$ の 3 指数をそれぞれ個人別に算出した。

2）冒発育成熟度は下記に述心゙る左前腕骨以遠 の骨部位をX線直接撮影によって評価した。

すなわち，前腕骨 Forearm Bones，手根筱 Carpal Bones, 中手骨 Metacarpal Bones, 手指 の基節骨 Proximal Phalanges, 中節带 Middle Phalanges, 未節骨 Distal Phalanges の三领骨合 計 Three Phalanges total および総甜垶点 All Bone Scores の 8 项目を中沢式骨作命秤点法 ${ }^{16)}$ と 大原式評点法 ${ }^{17)}$ を併用し，さらに，その他の身体

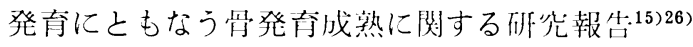
27)を参考にして骨端核の発参状態をとに骨発育 成熟の程度を評価した。

評価方法は，今回採用した大原式評点法 ${ }^{17)}$ 之中 沢式骨年令評点法 ${ }^{16)}$ による具発育成熟度の評価尺 度を採用した。その内容は次の通りである。

管状骨の評価（大原法）

1）管状骨（橈骨，尺骨，中手骨，指骨）飞つ いては $0 〜 9$ の10段階に分類して評価した。

0 点 骨核はまだ現われない。

1 点 小円形のボンャリした骨核の㓌影が現わ れる。

2 点 円形はやや大となり輪郭が明瞭となる。

3 点 骨核はさらに大となり輪郭に山!を生ず 
る。

4 点 輪郭の凹凸はさらに明膫となるが骨核の 幅は骨幹の幅より小さい。

5 点 骨格の幅と骨幹の幅とが一致する。

6 点，骨幹に対する骨核の縁がたれ下り (capping)，両者の間に空隙を残す。

7 点 骨核と骨幹の癒合が始まる。

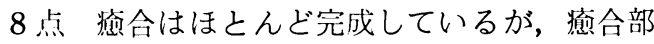
に連続した横線を認める。

9 点 疮合は完了して横線は消失する。

手根骨の評価（中沢法に同じ）

2）手根骨は以下に示す評価基準により $0 \sim 5$ の 6 段階に成熟度を分類して評価した。

0 点 骨格はまだ現われない。

1 点 小円形のボンャリした除影を認める。

2 点 陰影は增大したが，いまだ滑らかな円形 を示す。

3 点 核固有の形態を示しはじめ, 凹!!が生じ てくる。

4 点 核固有の分化がさらに進み, 隣接骨との 関節面が明膫となる。

5 点 成熟が完了し，核の周辺部は互いに重な り合ったように見える。

3） X線撮影のフィルムは四つ切り判を使用し た。この四つ切り判の使用によって末節骨も明暸 に陰影を垫めたので中沢法と異なり，指骨，末幯 骨屯評価の対像として採点に加えた。

4）以上の評価法によって骨発育成熟度を評価 すれば，完全成熟の成人においては指骨，末節骨 の合計点は 45 点，从幯骨 36 点，基節骨 45 点，中手 骨45点, 手根骨40点, 前椀骨遠位端18点で総骨評 点が 229 点になる。

測定方法と考察資料の作成法

1）以上述べた Rohrer, Kaup, Kawahata 指数 の 3 つの策養指数之䟫発育成熟度衦価 8 项目相互 間の相関係数を求め, $11 \times 11$ の相関 Matrix を作 成して関連度考察のための資料とした。

2）つぎに，各栄鉒指数の平均值と愫準偏算を 基準に，標本をそれぞれ 2 群(good - poor group) に分類して 2 群間の骨発育成熟度を比較 検討し た。すなわち, good group は各栄菁指数の X+ $0.43 \sigma$ 以上, poor group は $\mathrm{X}-0.43 \sigma$ 以下に 属する group である。したがって, good-poor
の各 group に所属する標本数は 理論上全体の約 $33 \%$ となる。

3） X線撮影法としての装置には中央レントゲ ン会社製の携带用 $\mathrm{X}$ 線装置 CR-20 MX（7万 KVP；20 MA）を使用した。投射距離は $100 \mathrm{~cm}$, 露出時間は 0.05 秒で，乙のために電子タイマーを 用いた。なお，放射線量は微量ではあるが被検者 の放射線防禦の立場から，鉛延板によって散乱線 量の防禦につとめたととを付記する。

\section{結果と考察}

表 1 は, Rohrer, Kaup, Kawahata 指数の各 栄養指数值扰よび骨発育成熟度の平均值と梆準偏 差，そして，男从別平均值の有意䍮の結果をそれ ぞれ項目別に示したものである。

これによれば，骨発育成熟度の各部位の平均值 は男子に比較して女子の場合はいずれも高い值を 示した。なお，男女間における性差の有意性は， 各部位とも危険率 $5 \%$ 以下の水準で有意差が認め られた。これらのととは，女子の骨発育成熟度が 男子に比べて早熟化傾向にあることを意味してい るものと考えられる。しかし，3つ0栄䬭指数の それぞれの平均值についてみれば，いずれも男女 間に有意差は認められなかった。

表 2 は, 3 つの栄䬶指数之骨発育成熟度との相 関係数を男女別に求めて示したものである。男子 に打ける Rohrer 指数では中節骨に，また Kaup 指数ではすべての骨部位に，そして，Kawahata 指数では指数值と手根骨, 川于冒, 中節骨, 三節 骨合計および総骨泙点との閣に有意な相関が認め られた。Rohrer 指数と中邻高との相関係数は 0.325, Kaup 指数において最も高い相関を示し た骨部位は中節骨で 0.415 ，ついで三领骨合計の 0. 411 であった。Kawahata 指数でも中豤骨との 相関係数は 0.485 と最も高い值を示し，ついで手 根骨の0.410，総骨評点0.397の順に有意な相関の 值を示した。さきに大原は，栄祉椇取量と骨発肖 成熟度との関係において, 男子の総骨評点, 三朎 吊合計との間に有意性のあるととを認めている。 このことに関連して表 2 を考察すれば， Rohrer， Kaup, Kawahata 指数はいずれも巾節骨との相関 が高く，それ故，3つの栄篒指数は中節骨の骨発 青成熟度を比較的高い信賴性ををって評価判定す 

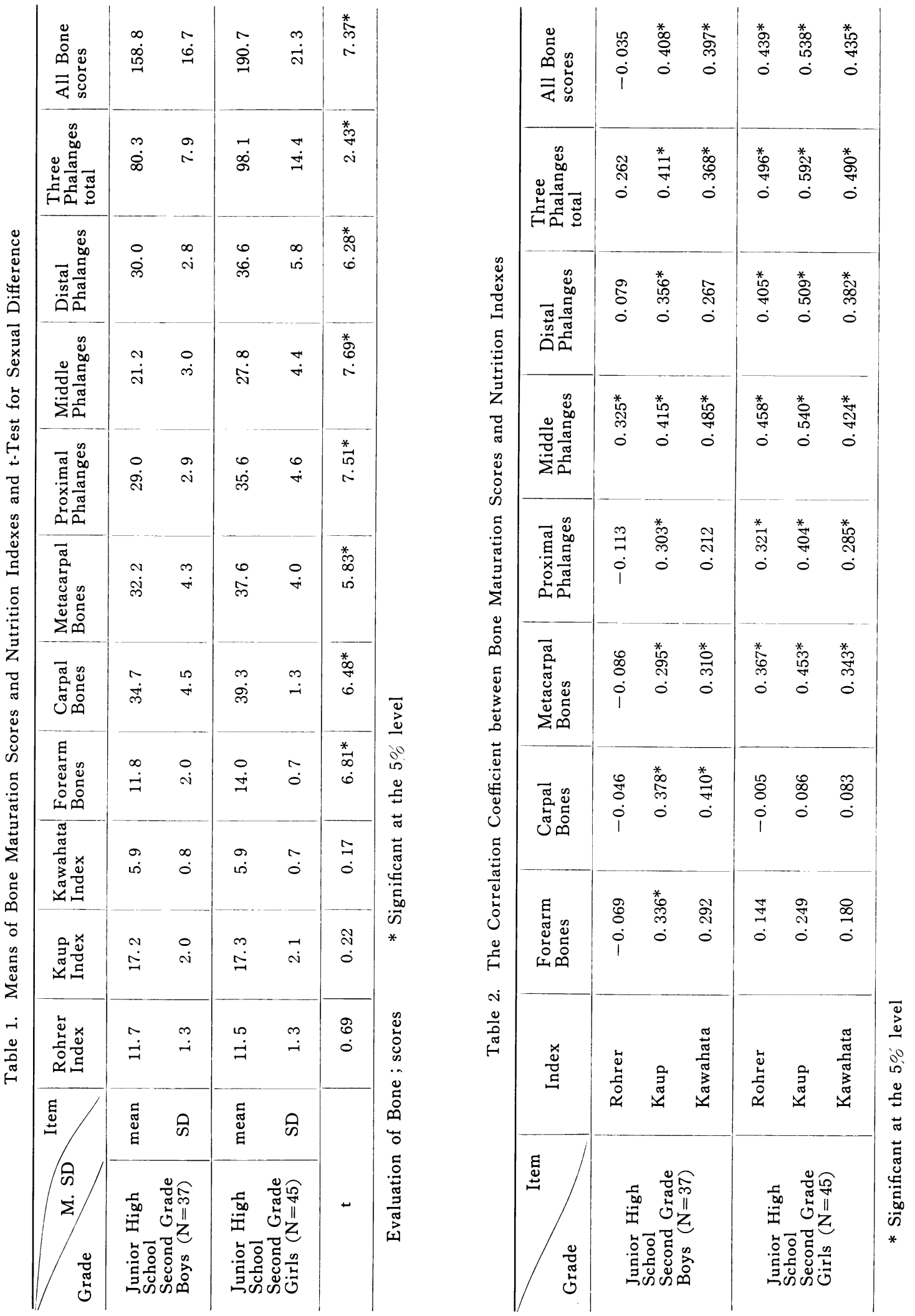
るととも可能と考えられる。なお，前腕骨の相関 係数が他の骨部位に比較して小さかったてとは, これからの骨部位の化骨が遅れていることを意味 するあのであろう。したがって，乙の時期におけ る骨の発育成熟速度は, 相対的にみて手根骨の方 が早く, 前腕骨以遠端において遅滞する倾向を示 した。とれらのととは，解剖学的骨癒合の知見と 一致している。

一方, 女子における 3 つの栄養指数值はすべて 中手骨，未節骨，三飾骨合計および総骨評点との 間において有意な相関を示していた。てのような 性差の出現は，女子が男子に比べてての時期にお ける骨発育の成熟速度と骨端核の化骨速度が早 く，またそれらの個人差が大きいためと考えられ る。とのととは，とりあなおさず女子が男子に先 んじて第 2 次性徵の完成期に近づいているととを 意味しており，男子の骨発育成熟度が女子より約 2 年遅れていることを指摘した大原の説と合致し ていた。

以上述べたように, 栄養指数と総骨評点との相 関が有意に高い值を示したてとの意味は, 笑養指 数を变量とする regression line から骨発育成熟度 の評価範囲について, あとで述べる研究の限界内

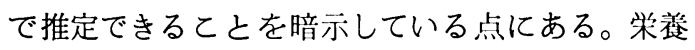
指数と有意な相関を示した骨部位は, 男子の場合, いずれも中節骨で, その相関の程度は, Rohrer 指 数: 0.325 , Kaup 指数: 0.415 , Kawahata 指数 : 0.485であった。女子の場合は男子と異なり，3つ の栄養指数 (Rohrer, Kaup, Kawahata) とも三 節合計において高く，それぞれの相関の程度は， 0.496，0.592，0.490であった。したがって，栄 锒指数は骨発育成熟度をこてに示したそれぞれの 相関係数の程度に有意に関係していたと考えられ る。しかし，乙の程度の相関からみれば，回帰力 程式によって骨発育成熟度を推定する個人的診断 評価および集団的診断評価としては，やや信頼度 に矢ける点もあるが，一応の目やすを知りうると

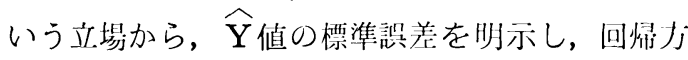
程式を求め，かつその信頼度について検討した。

困 1 〜図 3 には信頼度 $95.5 \%$ における上限およ び下限ラインを設定することによって骨発青成熟 度の推定範囲が示されている。また図中の印およ び○印は, 各被検者の栄盖指数化相応する骨発育
成熟度の実測值をプロットしたものである。な お，ここで骨発育成熟度の評価の指標は，当然生 体全体の骨発育成熟度をあらわすものでなければ ならないが, 本研究では骨全体の成熟度を栄養指 数という間接的指標を用い，乙れと相関係数の最 屯高かった中節骨をむって骨発育成熟度の代表值 としたてと。また身体の発育変量を組み合わせて 評価する方法として测定対象を第 2 次性徽期の過 程にある中学生男女を選び, 栄養指数の変量のみ で骨発育成熟度を推定する方程式を導いたことは 本研究の限界として考虑に入れなりればならない であろう。以下にそれぞれ栄養指数の骨年令の推 定方程式と推定値の標準䛊差を示した。

Rohrer Index の場合

推定力程式

男子 : $\widehat{Y}=12.42+0.75 \mathrm{X}$

女子 : $\widehat{\mathrm{Y}}=10.00+1.55 \mathrm{X}$

推定值の樌準䛊差

男子: S. E. $= \pm 0.15$

女子: S. E. $= \pm 0.38$

Kaup Index の場合

推定方程式

男子: $\widehat{Y}=10.48+0.62 X$

女子: $\widehat{\mathrm{Y}}=8.23+1.13 \mathrm{X}$

推定值の標準誤差

男子 : S. E. $= \pm 0.21$

女子 : S. E. $= \pm 0.35$

Kawahata Index の場合

推定方程式

男子: $\widehat{\mathrm{Y}}=10.47+1.82 \mathrm{X}$

女子 : $\widehat{\mathrm{Y}}=12.08+2.66 \mathrm{X}$

推定值の慓準訓!差

男子: S. E. $= \pm 0.21$

女子: S. E. $= \pm 0.29$

(注) $\mathrm{X}$ (栄鉒指数), $\widehat{\mathrm{Y}}$ (骨発育成熟度)

以上明示された各推定方程式に各個人の栄養指 数值を代入して求めた骨発育成熟度の推定值（ $\mathrm{Y}$ 值）の䌘準䛊差は0.15〜0.38に分布していること がわかった。このように，標準誤差がきわめて小 さかったことは，推定式によって算出された骨発 青成熟度の score の散布度がきわめて小であった ことを意味するから，母集団の真の骨発育成熟度 の平均值をかなり高い精度 ( \pm 2 S.E.) で推定し, 


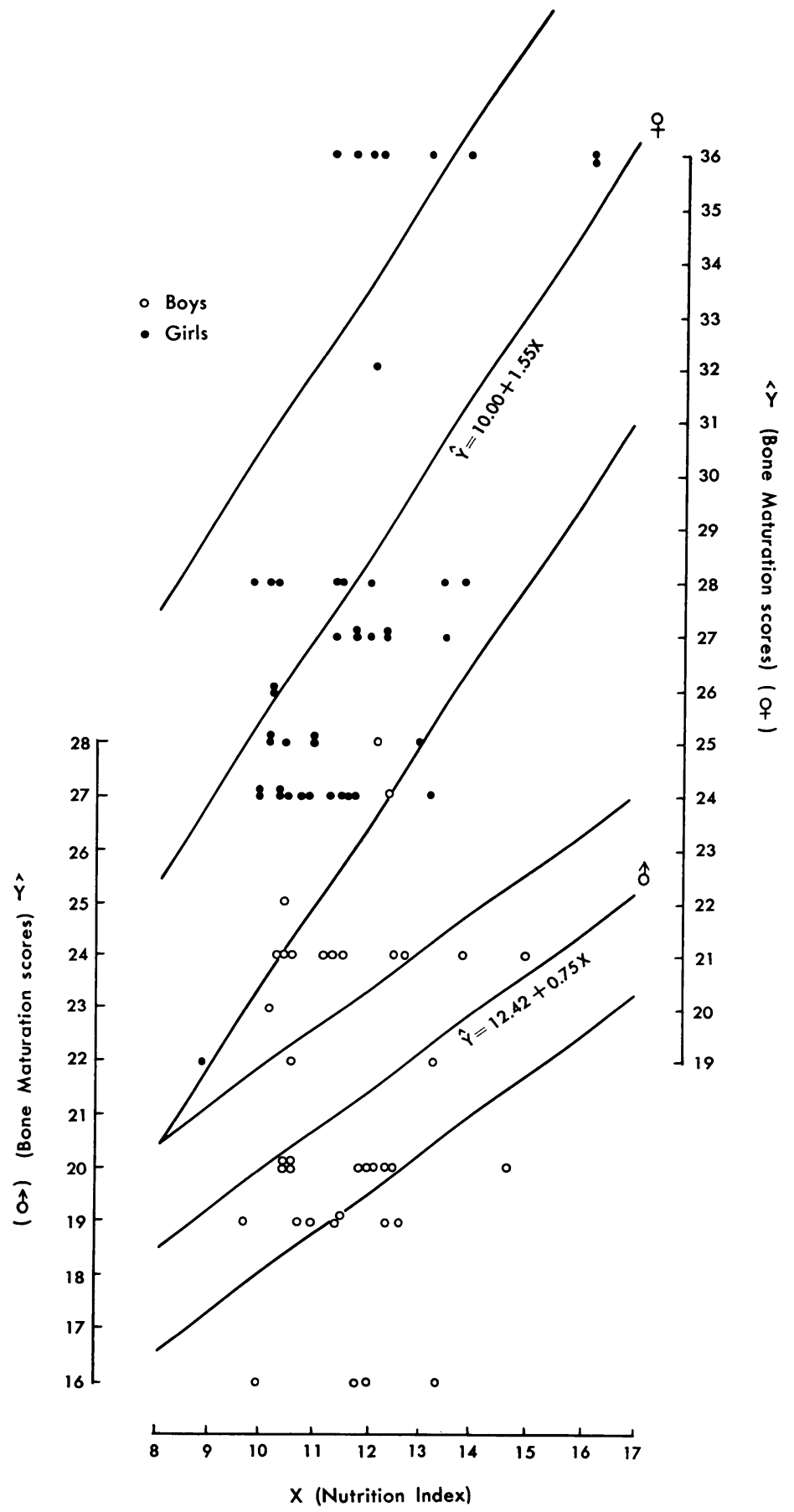

Fig. 1. Rohrer Index 


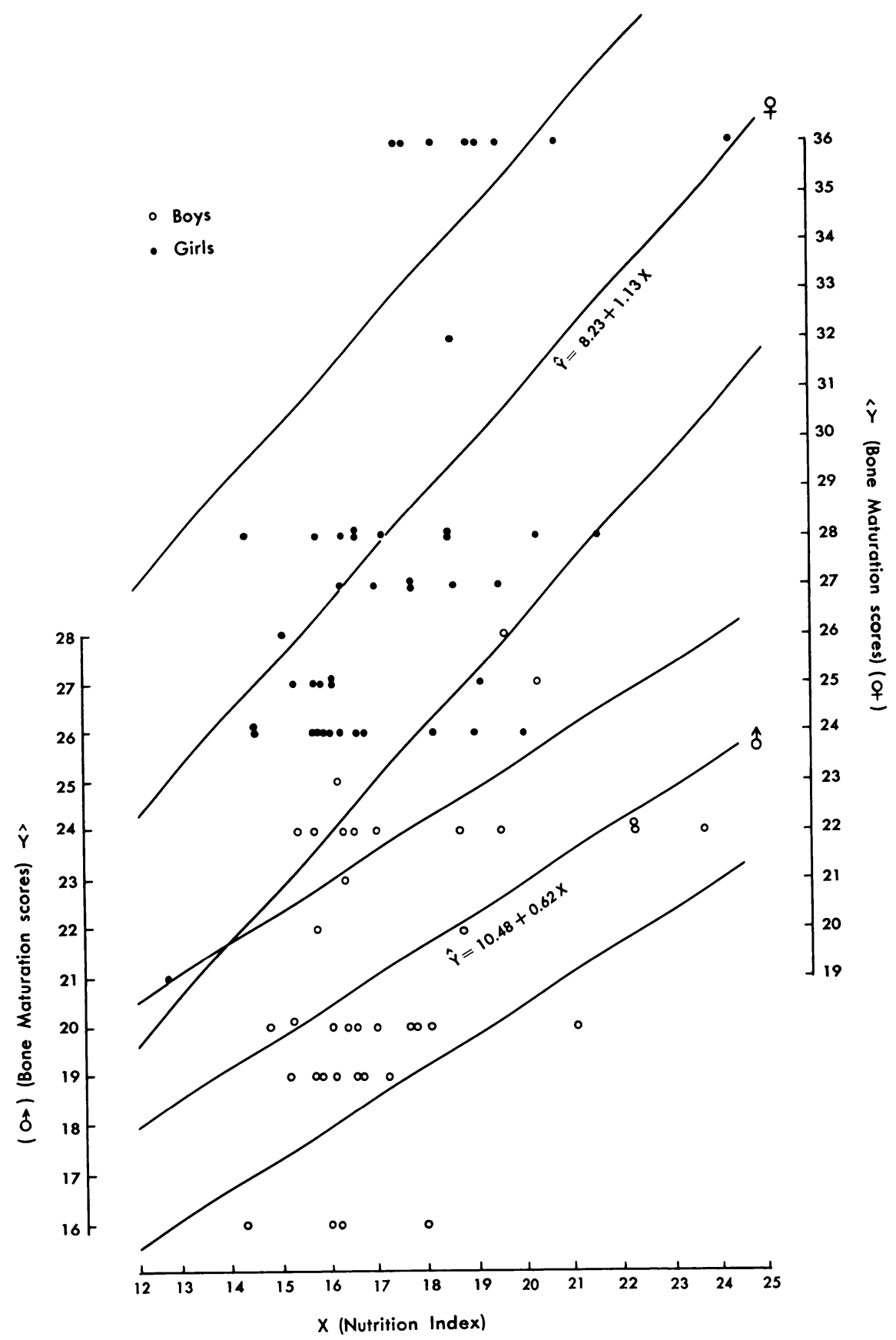

Fig. 2. Kaup Index

その信賴区間を明示できたととの意義は大きいと いえる。

さらに, 表 3 に示すように推定式に代入して求 められた骨発育成熟度の推定值の平均值と実测值 の平均値之の羛は，いずれも危険率 $1 \%$ 以下の水
準で有意性は認められなかった。

また表 4 に示されたように，中邻骨の推定值と 実测值との相関係数は, 各指数いずれも危険率 5 \%以下の水準で有意性が認められた。

以上の点からここに採用された推定式は，いず 


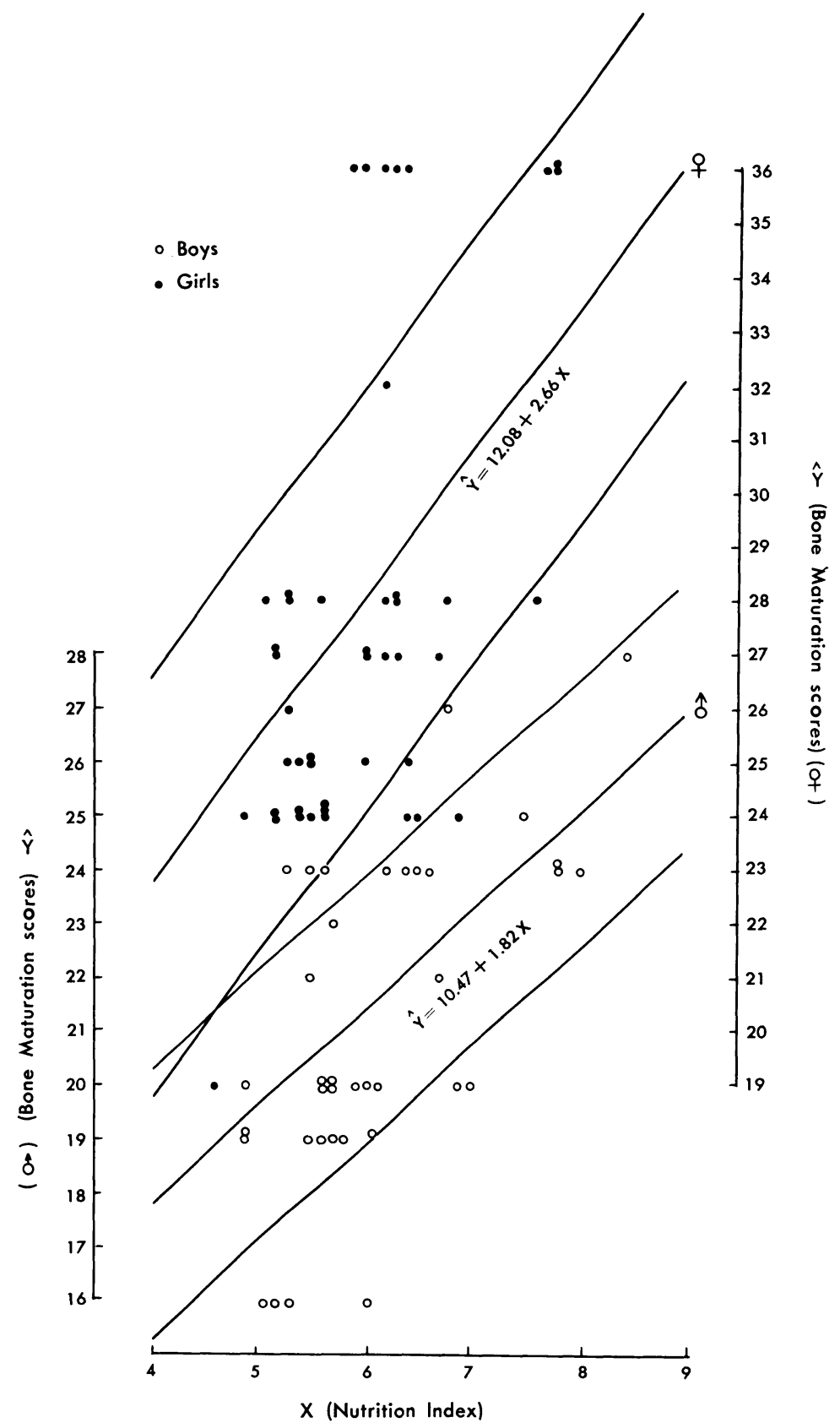

Fig. 3. Kawahata Index

れも信頼度が高く，かつ個人的䛦断評価のほか集 団的診断評価の目やすとして適用できることを叮 らかにするととができた。

表 5 は, 男子の Rohrer, Kaup, Kawahata 指数 の 3 つの栄養指数における good-poor 群間の骨 発育成熟度の有意差について検定した結果を骨部
位別に示したものである。表中の*印は危険率 5 \%以下の水準で有意差の認められた項目である。 すなわち， Rohrer 指数では， 2 群間に有意差は 認められなかったが, Kaup, Kawahata 指数では 基節骨を除き，他のすべての骨部位に有意差が認 められた。 
Table 3. t-Test of Difference between Measurement and Estimate Scores

\begin{tabular}{|c|c|c|c|c|}
\hline Index Sex & Item & $\begin{array}{l}\text { means of } \\
\text { mesurement } \\
\text { scores }\end{array}$ & $\begin{array}{l}\text { means of } \\
\text { estimate } \\
\text { scores }\end{array}$ & $\mathrm{t}$ \\
\hline \multirow{2}{*}{ Rohrer } & Boys & 21.2 & 21.2 & 0.00 \\
\hline & Girls & 27.8 & 27.6 & 0.16 \\
\hline \multirow{2}{*}{ Kaup } & Boys & 21 & 21.2 & 0.20 \\
\hline & Grils & 27.8 & 27.8 & 0.02 \\
\hline \multirow{2}{*}{ Kawahata } & Boys & 21.2 & 21.3 & 0.10 \\
\hline & Girls & 27.8 & 27.8 & 0.04 \\
\hline
\end{tabular}

Table 4. The Correlation Coefficients between Measurement and Estimate Scores of Middle Phalanges

\begin{tabular}{l|l|l}
\hline Index & Sex & $\begin{array}{c}\text { Correlation } \\
\text { Coefficients }\end{array}$ \\
\hline \multirow{2}{*}{ Rohrer } & Boys & $0.372^{*}$ \\
& Girls & $0.442^{*}$ \\
\hline \multirow{2}{*}{ Kaup } & Boys & $0.451^{*}$ \\
& Girls & $0.613^{*}$ \\
\hline \multirow{2}{*}{ Kawahata } & Boys & $0.437^{*}$ \\
\hline
\end{tabular}

* Significant at the 50 ; level

Table 5. $t$-Test of the Difference between Bone Maturation Scores in Two Groups (Nutrition Indexes, good and poor) (Junior High School Second Grade Boys)

\begin{tabular}{|c|c|c|c|c|c|c|c|c|c|c|}
\hline $\mathrm{Funs}^{2}$ & Index & & Rohrer & & & Kaup & & & awahat & \\
\hline Bones Name & Group & good & poor & $\mathbf{t}$ & good & poor & $\mathrm{t}$ & good & poor & $\mathrm{t}$ \\
\hline Forearm Bones & $\begin{array}{c}\text { mean } \\
\mathrm{SD}\end{array}$ & $\begin{array}{r}11.8 \\
2.4\end{array}$ & $\begin{array}{r}12.4 \\
1.3\end{array}$ & 0.77 & $\begin{array}{r}13.3 \\
1.5\end{array}$ & $\begin{array}{r}11.6 \\
1.6\end{array}$ & $2.55^{*}$ & $\begin{array}{r}13.3 \\
1.5\end{array}$ & $\begin{array}{r}11.1 \\
1.7\end{array}$ & $2.75^{*}$ \\
\hline Carpal Bones & $\begin{array}{c}\text { mean } \\
\mathrm{SD}\end{array}$ & $\begin{array}{r}34.3 \\
6.1\end{array}$ & $\begin{array}{r}35.7 \\
2.6\end{array}$ & 0.75 & $\begin{array}{r}38.2 \\
2.5 \\
\end{array}$ & $\begin{array}{r}34.4 \\
3.8\end{array}$ & $2.62 *$ & $\begin{array}{r}38.1 \\
2.6\end{array}$ & $\begin{array}{r}31.6 \\
5.4\end{array}$ & $3.07 *$ \\
\hline Metacarpal Bones & $\begin{array}{c}\text { mean } \\
\mathrm{SD}\end{array}$ & $\begin{array}{r}31.5 \\
5.1\end{array}$ & $\begin{array}{r}32.9 \\
1.8\end{array}$ & 0.92 & $\begin{array}{r}35.4 \\
3.9\end{array}$ & $\begin{array}{r}31.7 \\
3.2\end{array}$ & $2.51 *$ & $\begin{array}{r}35.3 \\
3.9\end{array}$ & $\begin{array}{r}30.6 \\
3.7\end{array}$ & $2.48^{*}$ \\
\hline $\begin{array}{l}\text { Proximal } \\
\text { Phalanges }\end{array}$ & $\begin{array}{c}\text { mean } \\
\mathrm{SD}\end{array}$ & $\begin{array}{r}28.5 \\
3.5\end{array}$ & $\begin{array}{r}29.5 \\
0.9\end{array}$ & 0.99 & $\begin{array}{r}31.1 \\
3.9\end{array}$ & $\begin{array}{r}28.8 \\
1.7\end{array}$ & 2.02 & $\begin{array}{r}31.1 \\
3.9\end{array}$ & $\begin{array}{r}28.1 \\
2.0\end{array}$ & 1.94 \\
\hline Middle Phalanges & $\begin{array}{c}\text { mean } \\
\mathrm{SD}\end{array}$ & $\begin{array}{r}21.8 \\
3.0\end{array}$ & $\begin{array}{r}21.1 \\
2.5\end{array}$ & 0.61 & $\begin{array}{r}23.7 \\
2.6\end{array}$ & $\begin{array}{r}20.6 \\
3.0\end{array}$ & $2.54^{*}$ & $\begin{array}{r}23.7 \\
2.6\end{array}$ & $\begin{array}{r}20.0 \\
3.4\end{array}$ & $2.45^{*}$ \\
\hline Distal Phalanges & $\begin{array}{c}\text { mean } \\
\mathrm{SD}\end{array}$ & $\begin{array}{r}30.5 \\
3.2\end{array}$ & $\begin{array}{r}29.7 \\
1.4\end{array}$ & 0.81 & $\begin{array}{r}32.2 \\
4.2\end{array}$ & $\begin{array}{r}29.1 \\
2.0\end{array}$ & $2.46^{*}$ & $\begin{array}{r}32.2 \\
4.2\end{array}$ & $\begin{array}{r}28.7 \\
2.0\end{array}$ & 3. $76^{*}$ \\
\hline $\begin{array}{l}\text { Three Phalanges } \\
\text { total }\end{array}$ & $\begin{array}{c}\text { mean } \\
\mathrm{SD}\end{array}$ & $\begin{array}{r}81.1 \\
8.8\end{array}$ & $\begin{array}{r}80.3 \\
3.8\end{array}$ & 0.30 & $\begin{array}{r}87.3 \\
9.9\end{array}$ & $\begin{array}{r}78.5 \\
5.7\end{array}$ & $2.78^{*}$ & $\begin{array}{r}87.3 \\
9.9\end{array}$ & $\begin{array}{r}76.8 \\
6.4\end{array}$ & $2.52^{*}$ \\
\hline All Bone scores & $\begin{array}{c}\text { mean } \\
\mathrm{SD}\end{array}$ & $\begin{array}{r}158.5 \\
20.2 \\
\end{array}$ & $\begin{array}{r}161.4 \\
7.5\end{array}$ & 0.48 & $\begin{array}{r}174.0 \\
16.3 \\
\end{array}$ & $\begin{array}{r}156.2 \\
12.7\end{array}$ & $2.97 *$ & $\begin{array}{r}173.8 \\
16.5\end{array}$ & $\begin{array}{r}150.0 \\
14.6\end{array}$ & $3.06^{*}$ \\
\hline
\end{tabular}

* Significant at the $5 \%$ level

一方，表 6 に示した女子の Rohrer 指数ではさ きに述へた男子の結果とは異なり，中節骨，末领 骨，三節骨合計および総骨評点において 2 群間に 有意差を認めた。また Kaup 指数では手根骨を 除き, Kawahata 指数では前腕骨, 手根骨を除く
その他の骨部位に有意差が認められた。

以上の分析結果から，栄稂指数が大となる傾问 のものは，総骨評点も大となることを意味してお り, 骨発育成熟度が促進しているものと解釈され る。このように, 栄養指数は骨発育成熟度との関 
Table 6. $\mathrm{t}$-Test of the Difference between Bone Maturation Scores in Two Groups (Nutrition Indexes, good and poor) (Junior High School Second Grade Girls)

\begin{tabular}{|c|c|c|c|c|c|c|c|c|c|c|}
\hline 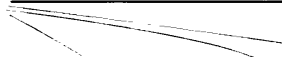 & Index & & Rohrer & & & Kaup & & & awahat & \\
\hline Bones Name & 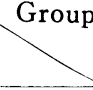 & good & poor & $\mathrm{t}$ & good & poor & $\mathrm{t}$ & good & poor & $\mathrm{t}$ \\
\hline Forearm Bones & $\begin{array}{c}\text { mean } \\
\mathrm{SD}\end{array}$ & $\begin{array}{r}14.0 \\
0.4\end{array}$ & $\begin{array}{r}13.8 \\
0.7\end{array}$ & 0.87 & $\begin{array}{r}14.3 \\
0.5\end{array}$ & $\begin{array}{r}13.7 \\
0.7\end{array}$ & $2.73^{*}$ & $\begin{array}{r}14.1 \\
0.5\end{array}$ & $\begin{array}{r}13.7 \\
0.7\end{array}$ & 2.00 \\
\hline Carpal Bones & $\begin{array}{c}\text { mean } \\
\mathrm{SD}\end{array}$ & $\begin{array}{r}39.7 \\
0.7\end{array}$ & $\begin{array}{r}39.5 \\
0.8\end{array}$ & 0.68 & $\begin{array}{r}39.7 \\
0.7\end{array}$ & $\begin{array}{r}39.4 \\
0.8\end{array}$ & 1.09 & $\begin{array}{r}39.6 \\
0.9\end{array}$ & $\begin{array}{r}39.2 \\
1.0\end{array}$ & 1.29 \\
\hline Metacarpal Bones & $\begin{array}{c}\text { mean } \\
\mathrm{SD}\end{array}$ & $\begin{array}{r}39.2 \\
4.1\end{array}$ & $\begin{array}{r}36.6 \\
2.8\end{array}$ & 1.97 & $\begin{array}{r}40.5 \\
3.9\end{array}$ & $\begin{array}{r}36.4 \\
2.8\end{array}$ & $3.42 *$ & $\begin{array}{r}39.8 \\
4.5\end{array}$ & $\begin{array}{r}36.2 \\
2.6\end{array}$ & 3. $10^{*}$ \\
\hline $\begin{array}{l}\text { Phoximal } \\
\text { Phalanges }\end{array}$ & $\begin{array}{c}\text { mean } \\
\mathrm{SD}\end{array}$ & $\begin{array}{r}37.0 \\
4.4\end{array}$ & $\begin{array}{r}34.1 \\
3.8\end{array}$ & 1.84 & $\begin{array}{r}38.0 \\
4.6\end{array}$ & $\begin{array}{r}34.3 \\
3.5\end{array}$ & $2.57 *$ & $\begin{array}{r}36.9 \\
4.8\end{array}$ & $\begin{array}{r}34.0 \\
3.5\end{array}$ & $2.16^{*}$ \\
\hline Middle Phalanges & $\begin{array}{c}\text { mean } \\
\mathrm{SD}\end{array}$ & $\begin{array}{r}29.9 \\
4.8\end{array}$ & $\begin{array}{r}25.7 \\
2.8\end{array}$ & $2.87 *$ & $\begin{array}{r}31.1 \\
4.6\end{array}$ & $\begin{array}{r}25.7 \\
2.7\end{array}$ & 4. $11 *$ & $\begin{array}{r}29.9 \\
4.7\end{array}$ & $\begin{array}{r}25.7 \\
2.6\end{array}$ & $3.50^{*}$ \\
\hline Distal Phalanges & $\begin{array}{c}\text { mean } \\
\mathrm{SD}\end{array}$ & $\begin{array}{r}39.5 \\
5.4\end{array}$ & $\begin{array}{r}34.3 \\
4.4\end{array}$ & $2.76^{*}$ & $\begin{array}{r}41.1 \\
4.6\end{array}$ & $\begin{array}{r}34.0 \\
4.1\end{array}$ & 4. $55^{*}$ & $\begin{array}{r}39.8 \\
5.3\end{array}$ & $\begin{array}{r}34.1 \\
4.6\end{array}$ & $3.57^{*}$ \\
\hline $\begin{array}{l}\text { Three Phalanges } \\
\text { total }\end{array}$ & $\begin{array}{c}\text { mean } \\
\mathrm{SD}\end{array}$ & $\begin{array}{r}105.8 \\
14.9\end{array}$ & $\begin{array}{r}89.7 \\
7.2\end{array}$ & 3. $69 *$ & $\begin{array}{r}110.2 \\
13.2\end{array}$ & $\begin{array}{r}90.8 \\
7.6\end{array}$ & $5.19^{*}$ & $\begin{array}{r}106.2 \\
14.7\end{array}$ & $\begin{array}{r}90.4 \\
7.6\end{array}$ & 4. $29^{*}$ \\
\hline All Bone scores & $\begin{array}{c}\text { mean } \\
\mathrm{SD}\end{array}$ & $\begin{array}{r}199.3 \\
17.6\end{array}$ & $\begin{array}{r}179.7 \\
8.7\end{array}$ & $3.81 *$ & $\begin{array}{r}204.7 \\
16.8\end{array}$ & $\begin{array}{r}179.8 \\
8.7\end{array}$ & $5.39 *$ & $\begin{array}{r}199.7 \\
18.0\end{array}$ & $\begin{array}{r}179.6 \\
9.1\end{array}$ & 4. $48^{*}$ \\
\hline
\end{tabular}

* Significant at the $5 \%$ level

連を则る1つの指㭢となりうるあのと考察されよ う。

それ故, 骨発育成熟度の評価法の立場から中学 生の骨発育成熟度を栄鉒指数から間接的に求好 推定式が考案されたととは意義あるものと考えら れる。

さらに，骨発青成熟度の評洒におけるより妥当 性の高い推定範囲を求めるためには，小学生・高 校生をも含めた多数標本の测定を行なうこと，さ らには総骨評点と栄養指数およびその他の予测変 量との重相関係数を求め, 多変量による重回崹方 程式から，骨発育成熟度を推定し評価するととな どが今後の課題である。

\section{要約および結論}

骨発育成熟度と初潮年令, あるいは，身体発育 変量などの関係については，井上，清水 ${ }^{9)}$ や高

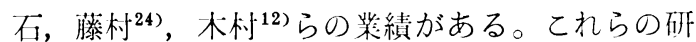
究は，いずれも悬発省成熟度と身体発育との関係 を単独変量相互間の関係によって纱らかにされて いる。そこで，本研究は身長・体重・夾高を複合 変量とする栄善指数之骨発青成熟度との関係を 11 項目相互間の相関係数によって考察し, 栄篒指数 による骨発育成熟度評価のための推定の範囲とそ の関連を明らかにした。そして、レントゲンによ る骨発育成熟度評価を用いないで，栄䬭指数值か ら直接骨発育成熟度を推定する方程式と $95.5 \%$ の 信頼度における評価範囲を明示しよう之試みた。 また個体別栄稂指数を good-poor の各 group に 分類して差の検定を行ない栄養指数が骨発育成熟 度を知る 1 指標となるか否かについても言及し た。

1）第 2 次性徵期にある男子の栄養指数之骨発 育成熟度 (中節骨) との相関係数についてみると， 
Rohrer 指数 $(\mathrm{r}=0.325)$, Kaup 指数 $(\mathrm{r}=0.415)$, Kawahata 指数 $(r=0.485)$ で各指数ともに有意な 相関が認められた。また女子についても, Rohrer, Kaup, Kawahata 指数の 3 つの栄筌指数は, 前 腕骨，手根骨を除きその他の骨部位とはいずれも 有意な相関を示すといった特徽が認められた。

とくに，三節骨合計ないし中唧骨との相関が高 かった。ちなみに, 男女共通の変量として考えら

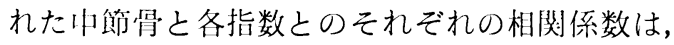
Rohrer指数: 0. 458, Kaup 指数: 0.540, Kawahata 指数 : 0.424 であった。

2）したがって，上記の考察結果より骨発育成 熟度を呼価しようとすれば，女子の場合，やや精 度は低下するが，実用性ないしは共通性という立 場から考察すると，男大とも中節骨によって骨発 育成熟度を推定することができるであろう。

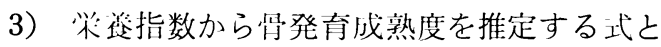
推定笵囲を本研究の限界内で本文中に示した。い ずれも推定式に代入して求められた推定值の平均 值と，実测值との差に有意性が認められなかった こと，また推定值と実測值との相関係数において 各指数いずれ屯高い有意性を認めたこと，さら に，推定值の骤準䛊差がきわめて小であったこと などから，個人的診断評価および集団的診断铗価 の目やすとして，ここに仃示された推定式はいず れ屯信頼度が高く邀用できると考えられる。

4）栄篒指数によって区分された 2 群間におけ る骨発育成熟度差を比較した埸合，男子 Rohrer 指数では骨発育成熟度に有意性は認められなかっ たが，Kaup，Kawahata 指数はともに基筑骨を 除き，その他のすべての骨部位では有意性が認め られた。

一方，女子では 3 指数之も骨発育成熟度は 2 群 間に有意着が認められた。

したがって, 発育段階にある中学生の栄篒指数 から骨発育成熟度を泙価する場合，栄養指数は宜 発育成熟度を推定する 1 つの指標になりうるであ 万う。

稿を終るに当りで協力をいただいた京都産業人 学名誉教授大原純吉先告ならびに京都女子大学三”它 義信教授に深甚なる謝意を表します。

（本稿の要旨は, 日本体逳学会第24可大会, 第2 8 回日本学校保健学会に打いて発表した。)

（受付 昭和 56 年 8 月 1 日)

\section{参考文 献}

1) Baldwin, A.L. (1967): Theories of Child Development. John Wiley and Sons, Inc. New York. 497-504.

2) Breckenridge, M.E. and Vincent, E. L. (1966) : Child Development, Physiological Growth through Adolescence, W. B. Saunders Company, Philadelphia. 495-533.

3) Briggs, G.M. (1979) : Nutrition and Physical Fitness. 10th Ed., W. B. Saunders Company, Philadelphia. 3-20.

4) Elkind, D. and Weiner, I. B. (1978): Development of the Child. John Wiley and Sons, Inc. New York. 155-161.

5) Grinder, R.E. (1973) : Adolescence, John Wiley and Sons, Inc. New York. 49-85.

6) Grinder, R.E. (1978): Adolescence. 2th Ed., John Wiley and Sons, Inc. New York. 48-79.

7）日比逸郎（1968）：肥渵判定基準について, 健康 教空色, 208, 25-27.

8）井上 俊 (1961)：栄養判定の意義と力法に対 する批判, 学校保健研究, 12, 2-8.

9) Inoue, T. and Shimizu, M. (1965) : Physical and skeletal growth and development of Japanese Children, The Japan Society for the promotion of Science.

10）川畑愛義（1968）：学望期の栄学学，第 5 版， 医歯薬出版 K K, 東京, 109-112.

11) Kawahata, A., Matsuura, Y. and Konishi, H. (1970) : A Study on the Nutrition Indices. Jap. J. Phys. Educ., 14, 149-154.

12) Kimura, K. (1972) : Skeletal maturation in Japanese A new analytical method. J. Anthrop. Soc. Nippon, 80, 319-336.

13）小西愽喜, 大山良徳 (1973)：栄養指数の判別 領域に関する検討 (1) 栄䬭指数と運動能力・機 能との関係, 学校保健研究, 15, 452-456.

14）小西博点, 川畑愛義, 大山良徳, 三宅義信, 三 木直之（1971）：栄養判定基準に関する研劣， 体育学研究, 15, 117-123.

15） 円山槙雄，松田彦治，大枷達雄，佐藤絢子 (1953)：手の骨の発育に関する硎先，第23回日 本衛生学会総会号, 8, 60 .

16）中沢 修（1959）：骨年令評価法, 日本整形外 
科学会誌, 33, 839-863.

17）大原純吉（1971）：小中学徒の身体の発育発達 之骨成熟任関する研労，学校保健研究，13， 109-120.

18）大原純吉（1971）：小中学徒の身体の発育柋達 之具成熟江関する研究, 第 1 篇, 第 2 篇, 学校 保健研究, 13, 167-174.

19）大原純吉（1971）：小中学徒の身体の発有㥕達 之具成熟江関する研究，第 3 篇，学校保健研 劣, 13, 212-216.

20）大原純吉（1971）：小中学徒の身体の発有発達 之骨成熟任関する研究, 第 4 篇, 学校保健研 劣, 13,373-379.

21）大山良徳（1970）：体力づくりと身体柔軟性, 不昧堂, 東京, 104-199.

22）高石昌弘（1968）：肥満判定基準について，健
尿教室, 208, 11-18.

23）高石昌弘, 藤村京子（1975）：思春期発育飞関 する縱断的研觉一贯年令による身長年開增加量 および初潮件令の検討，小児科学脌鑑（197579年:度版)。180-184.

24) Tanner, J. M. (1962) : Growth at Adolescence, 2nd Ed., Blackwell Scientific Pub. lications Ltd. London. 121-130.

25）吕洞文倠，川畑愛我，松浦義行，大原純占 （1968）：骨成熟を制約する諸要团，第38回日本 衛生学会総会号, 23, 55.

26）吉阔文雄, 川畑愛義, 松浦義行, 大山良徳, 八 木 保, 大原純吉 (1969)：骨成熟度判定㳊関 する簡便法, 第39回日本衛生学会総会号, 24, 103. 